DOI:10.2478/rrlm-2019-0040

\title{
The influence of hemodialysis on FibroTest parameters
}

\author{
Olga Hilda Orasan ${ }^{1 \#}$, Iulia Breaban ${ }^{2 \#}$, Andreea Maria Stefan², \\ Adela Sitar-Taut ${ }^{1}$, Sorina Cezara Coste $^{2}$, Ioan Alexandru Minciuna ${ }^{3}$, \\ Teodora Alexescu ${ }^{1}$, Angela Cozma ${ }^{1 \#}$, Laura Urian ${ }^{4 *}$, Remus Aurel Orasan ${ }^{5}$ \\ 1. $4^{\text {th }}$ Medical Department, "Iuliu Hatieganu” University of Medicine and Pharmacy Cluj-Napoca, \\ Romania \\ 2. "Prof. Dr. Octavian Fodor" Regional Institute of Gastroenterology and Hepatology, Cluj-Napoca, \\ Romania \\ 3. Rehabilitation Hospital, Cluj-Napoca, Romania \\ 4. Hematology Department, "Iuliu Hatieganu” University of Medicine and Pharmacy Cluj-Napoca, \\ Romania \\ 5. Nefromed Dialysis Centers, Cluj-Napoca, Romania
}

\begin{abstract}
Chronic hepatitis $C$ viral infection is an important cause of morbidity and mortality in patients with end-stage renal disease treated with hemodialysis. Liver fibrosis represents a main determinant of liver disease prognosis and clinical management, and its assessment by liver biopsy can decide treatment allocation. Although liver biopsy is the gold standard for staging liver fibrosis, it is an invasive procedure associated with complications that are more prevalent in patients with end-stage renal disease. FibroTest represents a surrogate marker of fibrosis which evaluates the levels of apolipoprotein A1, total bilirubin, haptoglobin, gamma-glutamyltransferase and $\alpha 2$-macroglobulin, generating a score that indicates the level of fibrosis. Discrepancies were observed in clinical practice between FibroTest score and histopathological findings. The aim of this study was to evaluate how hemodialysis influences the level of each FibroTest parameter and the final score. The systematic literature review conducted by us suggests that hemodialysis induces a reduction in apolipoprotein A1, haptoglobin and bilirubin levels, with an increase in gamma-glutamyltransferase and alpha-2-macroglobulin levels. In conclusion, hemodialysis modifies the levels of FibroTest parameters, suggesting that it may also have an impact on the accuracy of liver fibrosis assessment in hemodialysis patients.
\end{abstract}

Keywords: hemodialysis, apolipoprotein A1, bilirubin, alpha-2-macroglobulin, haptoglobin, gamma-glutamyltransferase

Received: 15 th July 2019; Accepted: $26^{\text {th }}$ September 2019; Published: $21^{\text {st }}$ October 2019

\footnotetext{
* Corresponding author: Laura Urian, Hematology Department, "Iuliu Hatieganu" University of Medicine and Pharmacy Cluj-Napoca, Romania. E-mail: urianlaura@yahoo.com

\# These authors equally contributed to this paper.
} 


\section{Introduction}

Hemodialysis (HD) patients are at high risk of acquiring hepatitis $\mathrm{C}$ virus (HCV). The prevalence of chronic viral hepatitis $\mathrm{C}$ is high in this population (up to $60 \%$ ) due to nosocomial spread $(1,2)$.

Patients undergoing HD have a higher prevalence of HCV infection than the general population. Despite the development of effective direct-acting antiviral agents for the treatment of hepatitis $\mathrm{C}$, acquisition of $\mathrm{HCV}$ continues to occur in dialysis centers worldwide (3).

In Romania, the most prevalent HCV genotype is genotype $1,93.46 \%$ of patients having the genotype 1B (4).

Among the eligibility criteria, the level of fibrosis is an important factor (5). Liver biopsy is still considered the gold standard for the staging of fibrosis and the evaluation of necroinflammatory activity, despite its limitations: invasive, it does not allow a dynamic evaluation of fibrosis and life-threatening complications $(6,7)$. Also, this reference method is associated with up to $20 \%$ diagnostic errors in the staging of the disease (8). In addition, nephrologists hesitate to indicate liver biopsy in patients with end-stage renal disease (ESRD) because of platelet dysfunctions and the significant risk of hemorrhage. The severity of fibrosis can be estimated using biochemical indices such as serum hyaluronic acid $(9,10)$, the aspartate aminotransferase-to-platelet ratio index (APRI), the aspartate aminotransferase/ alanine aminotransferase (AST/ALT) ratio, the Fibrosis 4 (Fib-4) score, FibroTest $(11,12)$, and the measurement of liver stiffness with transient elastography (FibroScan) $(13,14)$.

The novelty of this review consists of evidencing the main variations of each parameter used in calculating the FibroTest score in hemodialysis patients, and how these changes may influence the final score (stage of fibrosis). FibroTest (FT) is a surrogate marker of fibrosis and it combines the determination of serum levels of $\alpha_{2}$-macroglobulin $\left(\alpha_{2} M\right)$, haptoglobin, apolipoprotein A1 (ApoA1), total bilirubin (TB), gamma-glutamyltransferase (GGT) to assess the level of liver fibrosis. Total bilirubin, $\alpha_{2} \mathrm{M}$ and GGT concentrations significantly increase with severe fibrosis, whereas haptoglobin and ApoA1 levels decrease (15).

Imbert-Bismut et al. reported that the FT score in $\mathrm{HCV}$ patients had a high negative predictive value $(100 \%$ certainty of absence of significant fibrosis (F2-F4)) for scores $\leq 0.1$, and a high positive predictive value ( $91 \%$ certainty of presence of significant fibrosis) for scores $\geq 0.6$. In such clear-cut cases, liver biopsy could be definitely avoided (16). However, several questions persist concerning the discrepancies between FT scores and histopathological findings within the HD population.

The accuracy of certain non-invasive procedures to predict the stage of liver fibrosis is significantly different in non-uremic patients versus uremic patients on hemodialysis.

Comparing Transient Elastography (TE), FT, and APRI scores in non-uremic patients based on the area under the ROC curve (AUC) values shows a similar diagnostic performance between them, with a slightly better accuracy of TE and FT compared with APRI score (17). In the case of HD patients, the situation is slightly different, as evidenced by several studies $(14,18)$. TE is superior to APRI, FT, and Fib-4 score in assessing the severity of hepatic fibrosis. Liu et al. further outline that the area under the ROC curve is higher in HD patients evaluated by TE compared with non-uremic patients in predicting a fibrosis stage F2 and F3, and is similar in the case of F4 stage (14).

Furthermore, the APRI score in HD patients has a superior accuracy in evaluating fibrosis stage compared with FT (19). However, in this group of patients the major strength of APRI score is to exclude significant liver fibrosis $(9,14)$. 
Although in non-uremic patients FT represents a valuable tool in assessing the stage of liver fibrosis, in HD patients its accuracy is lower compared with other tests such as TE and APRI.

\section{Aim of the study}

In the present study, we reviewed the influence of hemodialysis on FT parameters: apolipoprotein A1, total bilirubin, haptoglobin, gamma-glutamyltransferase, and $\alpha_{2}$-macroglobulin.

\section{Methods}

\section{Search strategy}

In the current study, we integrated five different literature reviews evaluating the influence of hemodialysis on each FT parameter.

A systematic web-based literature search of all publications in PubMed was conducted between April and September 2018 using several combinations of keywords ("hemodialysis"[All fields] AND "apolipoprotein A1"[All fields]; "hemodialysis"[All fields] AND "bilirubin"[All fields]; "hemodialysis"[All fields] AND "haptoglobin"[All fields], "hemodialysis"[All fields] AND "gamma-glutamyltransferase"[All fields], "hemodialysis"[All fields] AND " $\alpha_{2}$-macroglobulin"[All fields], "hemodialysis"[All fields] AND "fibrotest"[All fields]).

\section{Inclusion and exclusion criteria}

The inclusion criteria for primary studies required the following features:

- the studies had to be conducted on adult human patients with chronic kidney disease (CKD) undergoing HD

- published between January 2008 and August 2018

- focused on the impact of HD on each FT parameter or on the effect of HD on the FibroTest score itself

- both prospective and retrospective studies were acceptable.
The following were excluded:

- case reports

- articles that included pediatric patients (under 18 years old)

- articles referring only to peritoneal dialysis

- studies presenting the effect of different substances (drugs, toxins, vitamins) on the level of each FT parameter. Studies in patients undergoing treatments that could influence liver fibrosis stage were excluded (e.g. HCV/ HIV co-infected patients undergoing antiretroviral treatment).

A total of 858 articles were retrieved. Five hundred and thirty-five articles were published before January 2008 and were, therefore, excluded. Of the remaining 323 articles, 258 articles used human subjects. After reading the abstracts and the full text of all candidate articles, only 30 articles met all the inclusion and exclusion criteria. Therefore, the effect of HD on ApoA1 was reviewed in 17 articles, on bilirubin in 9 articles, on GGT in 3 articles, on haptoglobin in one article and on $\alpha_{2} \mathrm{M}$ in no article. Nevertheless, there were too few articles referring to $\alpha_{2} \mathrm{M}$ and haptoglobin that met all the inclusion and exclusion criteria, which is why in the case of these substances, all the articles found using the previously mentioned combinations of keywords were included, irrespective of the publication date.

A final number of 31 articles were reviewed and further summarized regarding each FT parameter separately (Figure 1).

\section{Methodological quality assessment}

Each of the studies meeting the inclusion criteria was analyzed by two independent reviewers. Data were presented according to the Preferred Reporting Items for Systematic Reviews and Meta-analyses (PRISMA) guidelines ${ }^{20}$. Consensus in disagreements was reached by referral to a third reviewer. 


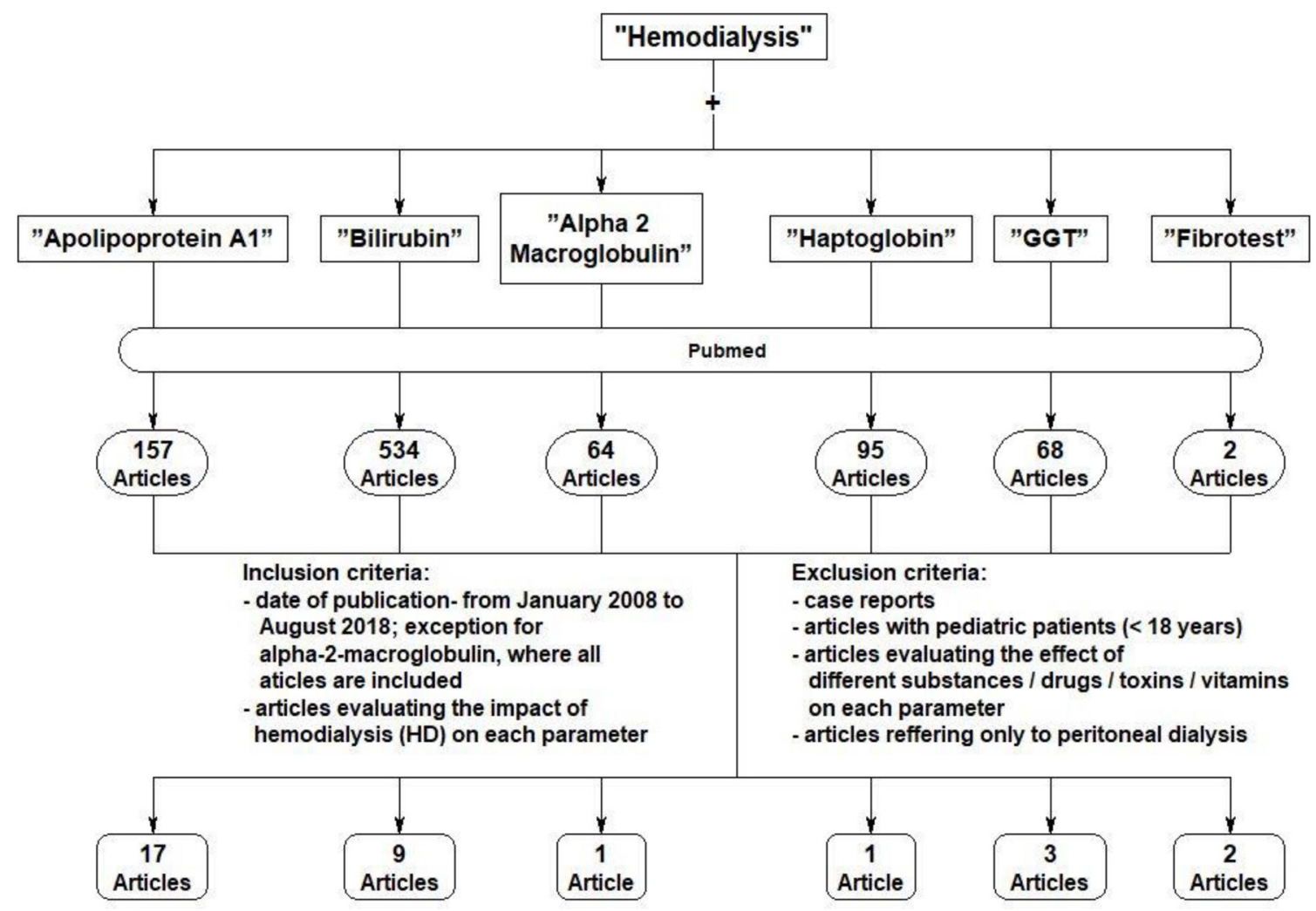

Fig. 1. Flow diagram of the potential articles. Inclusion and exclusion criteria. Apart from evaluating the effects of HD on each FT parameter, the study also aimed to analyze the effect of HD on the final score indicated by FT. Therefore, we extended our literature search in PubMed using the terms "hemodialysis"[All fields] and "fibrotest"[All fields]. Only two articles were identified.

\section{Results}

\section{Apolipoprotein A1}

ApoA1 is synthesized in the liver and the gut, representing approximately $70 \%$ of the high-density lipoprotein (HDL) content $(21,22)$.

The main functions of ApoA1 include reverse cholesterol transport (22-24), anti-inflammatory and antioxidant effects due to its binding to paraoxonase 1 (PON1) - the enzyme that prevents the formation of oxidized low-density lipoprotein (LDL).

HDL metabolism is initiated in the liver and intestine by the secretion of ApoA1, which attaches to macrophages in the arterial wall via ATP-binding cassette transporter (ABCA1), a receptor that initiates the flux of free cholesterol and phospholipids into the surface of HDL (25), forming nascent pre- $\beta$-HDL. Once in the circulation, pre- $\beta$-HDL particles interact with lecithin-cholesterol acyltransferase (LCAT) )(24). LCAT is a key constituent of HDL, which serves a dual function as phospholipase 2 and acyl-CoA cholesterol acyltrasferase, playing a crucial role in reverse cholesterol transport and HDL maturation (26).

Apart from LCAT and ABCA1, there are other enzymes that control the levels of ApoA1 and HDL, such as cholesteryl-ester transfer protein (CETP) and phospholipid transfer protein (PTLP) (26,27). PTLP transfers phospholipids 
and free cholesterol from triglyceride-rich lipoproteins to HDL, phospholipids between HDL particles, and facilitates cholesterol efflux from cells (26). CETP catalyzes the transfer of cholesteryl esters from HDL to LDL in exchange for triglycerides (26).

In patients with CKD or ESRD, the metabolism of HDL and ApoA1 is changed, their decreased levels being caused by increased catabolism and decreased production $(21,25)$. Some studies $(28$ 30 ) suggest that an explanation for the reduced levels of HDL and ApoA1 can be attributed to the levels of enzymes involved in their metabolism, such as decreased levels of ABCA1, LCAT, PON1 and unchanged levels of PTLP and CETP. As a consequence, the reverse cholesterol transport is inhibited and the interaction of ApoA1 with macrophages via ABCA1 is altered. The main effect of hemodialysis on the level of ApoA1 is to lower it $(21,22,24,28,30-34)$.

In vivo kinetic studies revealed that ApoA1, the main apolipoprotein of HDL, is catabolized at a faster rate in hemodialyzed patients, leading to a decreased ApoA1 level. A study (33) suggested that decreased LCAT and increased CETP may, at least in part, account for the increased catabolism of ApoA1.

Another explanation can be the presence of antiApoA1-IgG that tends to correlate with dialysis vintage. In one study (22), a significant association was found between dialysis vintage and anti-ApoA1-IgG positivity. Moreover, dialysis vintage was found to be significantly longer in anti-ApoA1-IgG negative patients (22).

Along with a lower level of ApoA1, some studies have highlighted certain abnormalities in the HDL profile of hemodialysis patients. These include: lower HDL apolipoprotein levels, a lower content of lipoprotein A1, A2 and a high content of pre- $\beta$-HDL compared with healthy patients (24). This abnormal HDL profile mirrors the profile found in individuals with genetic LCAT deficiency and probably reflects the plasma ac- cumulation of the cholesteryl-ester-poor ApoA1 containing discoidal HDL particles which cannot mature into spherical HDL particles of cholesterol (24).

Uremic plasma also tends to reduce the level of ApoA1. Hemodialysis, instead of eliminating the previously mentioned effect, has a tendency to perpetuate it, although its main role is to clear uremic toxins $(21,35)$.

In a study of Moradi et al. (36), compared with normal plasma, both pre-dialysis and post-dialysis plasma lowered ApoA1 mitochondrial ribonucleic acid (mRNA) abundance in HepG2 human liver cancer cell line to the same extent. This finding suggests that the toxins responsible for the inhibition of ApoA1 expression are not removed by hemodialysis. The authors also observed that the molecules responsible for this effect are larger than $30 \mathrm{kDa}$ and cannot be removed by hemodialysis (36).

Another effect of hemodialysis on lipid metabolism would lead to moderate hypertriglyceridemia, lower HDL-cholesterol, ApoA1 and HDL particle concentrations, as well as PON1 activity, and increased oxidized LDL levels (37). Wu et al. reported that dyslipidemia and the cholesterol efflux role in ESRD patients were not improved by HD, this being contrary to what HD is supposed to induce throughout the clearance of uremic toxins (35). The same study demonstrated a decreased serum triglyceride level and an increased HDL level in ESRD patients dialyzed with high-flux polysulfone membranes, but not in patients dialyzed with cellulose ester membranes (35) (Table 1).

\section{Bilirubin}

Bilirubin is produced in the reticuloendothelial system, as the end product of heme catabolism, derived from the oxidation of heme from hemeproteins (38).

Bilirubin is a water-insoluble compound that requires glucuronidation by a microsomal enzyme, 
Table 1. The effect of hemodialysis on the level of ApoA1

\begin{tabular}{|c|c|c|c|}
\hline Authors & Study type & $\begin{array}{l}\text { Number } \\
\text { of } \\
\text { patients }\end{array}$ & Results \\
\hline $\begin{array}{l}\text { Moradi et al., } \\
2012(21) \\
\end{array}$ & $\begin{array}{l}\text { Analytical prospective } \\
\text { cohort study }\end{array}$ & $\begin{array}{l}\text { Cellular } \\
\text { cultures }\end{array}$ & $\begin{array}{c}\text { Uremia lowers ApoA1 production by reducing RNA sta- } \\
\text { bility. }\end{array}$ \\
\hline $\begin{array}{l}\text { Pruijm et al., } \\
2012(22)\end{array}$ & Cross-sectional study & 66 & $\begin{array}{l}\text { The prevalence of anti-ApoA1-IgG is high ( } 20 \%) \text { in pa- } \\
\text { tients on maintenance hemodialysis. The antibody titer is } \\
\text { associated with dialysis vintage. }\end{array}$ \\
\hline $\begin{array}{l}\text { Rolla et al., } \\
2015 \text { (23) }\end{array}$ & Prospective study & 142 & $\begin{array}{c}\text { ApoA1 levels were significantly lower in hemodialysis } \\
\text { patients than in controls. }\end{array}$ \\
\hline $\begin{array}{l}\text { Calabresi et al., } \\
2014(24)\end{array}$ & $\begin{array}{c}\text { Analytical transversal } \\
\text { study }\end{array}$ & 288 & $\begin{array}{c}\text { ApoA1 levels were lower in hemodialysis patients than in } \\
\text { controls. }\end{array}$ \\
\hline $\begin{array}{l}\text { Moradi et al., } \\
2008(25)\end{array}$ & $\begin{array}{l}\text { Analytical transversal } \\
\text { study }\end{array}$ & 45 & $\begin{array}{l}\text { End-stage renal disease patients on hemodialysis exhibited } \\
\text { significant reductions in ApoA1 levels compared to the } \\
\text { control population. }\end{array}$ \\
\hline $\begin{array}{l}\text { Pahl M V et al., } \\
2009(26)\end{array}$ & $\begin{array}{l}\text { Analytical transversal } \\
\text { study }\end{array}$ & 42 & $\begin{array}{l}\text { Patients with end-stage renal disease on maintenance he- } \\
\text { modialysis had significantly reduced plasma ApoA1 con- } \\
\text { centrations compared to the control population. }\end{array}$ \\
\hline $\begin{array}{l}\text { Kaysen G A et } \\
\text { al., } 2014(27)\end{array}$ & Prospective cohort study & 266 & $\begin{array}{l}\text { During one year of observation, ApoA1 levels decreased } \\
\text { from baseline in patients initiated on hemodialysis in the } \\
\text { first two quarters and then returned to baseline values by } \\
\text { the end of the observation year. }\end{array}$ \\
\hline $\begin{array}{l}\text { Honda } \mathrm{H} \text { et al., } \\
2015(28)\end{array}$ & Prospective cohort study & 111 & $\begin{array}{l}\text { The levels of ApoA1 decreased according to the chronic } \\
\text { kidney disease severity. } \\
\text { The levels of ApoA1 were similarly decreased in patients } \\
\text { with CKD5 and CKD5 on hemodialysis compared to those } \\
\text { having CKD stage } 2 \text { or } 3 \text {. }\end{array}$ \\
\hline $\begin{array}{l}\text { Ribeiro S et al., } \\
2012(29)\end{array}$ & Prospective cohort study & 205 & $\begin{array}{l}\text { Patients on hemodialysis presented lower levels of ApoA1 } \\
\text { than controls. }\end{array}$ \\
\hline $\begin{array}{l}\text { Kimak E et al., } \\
2011(30)\end{array}$ & Prospective cohort study & 193 & Hemodialyzed patients had lower levels of ApoA1. \\
\hline $\begin{array}{l}\text { Lokesh S et al., } \\
2016(31)\end{array}$ & $\begin{array}{l}\text { Comparative cross-sec- } \\
\text { tional study }\end{array}$ & 80 & $\begin{array}{c}\text { The mean level of ApoA1 was significantly lower in pa- } \\
\text { tients receiving hemodialysis. }\end{array}$ \\
\hline $\begin{array}{l}\text { Ikewaki K, } \\
2014(32)\end{array}$ & Analytical study & - & $\begin{array}{l}\text { ApoA1 levels were significantly decreased in hemodialy- } \\
\text { sis patients comparative to controls. The decreased levels } \\
\text { of ApoA1 in patients with end-stage renal disease on } \\
\text { hemodialysis were primarily due to the increased rate of } \\
\text { catabolism. }\end{array}$ \\
\hline $\begin{array}{l}\text { Yeo Y et al., } \\
2009(33)\end{array}$ & $\begin{array}{l}\text { Retrospective case-con- } \\
\text { trol study }\end{array}$ & 252 & $\begin{array}{l}\text { Chronic dialysis patients showed significantly lower levels } \\
\text { of ApoA1 than controls. }\end{array}$ \\
\hline $\begin{array}{l}\text { Samouilidou } \\
\text { EC et al., } 2008 \\
(34)\end{array}$ & Prospective cohort study & 51 & $\begin{array}{c}\text { ApoA1 concentrations were higher after hemodialysis than } \\
\text { before hemodialysis. }\end{array}$ \\
\hline $\begin{array}{l}\text { Wu S et al., } \\
2015(35)\end{array}$ & Prospective cohort study & 79 & $\begin{array}{l}\text { ApoA1 significantly decreased in end-stage renal disease } \\
\text { patients. After hemodialysis, the levels of ApoA1 were } \\
\text { significantly reduced. }\end{array}$ \\
\hline $\begin{array}{l}\text { Holzer M et al., } \\
2011(37)\end{array}$ & Prospective cohort study & 46 & $\begin{array}{l}\text { The reduced cholesterol efflux of uremic HDL is linked to } \\
\text { the depletion of HDL-associated ApoA1. }\end{array}$ \\
\hline
\end{tabular}


uridine diphosphate glucuronosyltransferase 1A1 (UGT1A1), in order to be excreted.

The most important properties of bilirubin include: antioxidant effects, cytoprotective effects, anti-inflammatory effects, lipid-lowering properties and also antiatherogenic properties $(38,39)$. Apart from the association with lower oxidative stress, elevated bilirubin levels can augment endothelial function/endothelial-dependent vasodilatation (38). A study (38) indicated that serum total bilirubin concentrations were positively related to collateral development, by increasing NO (nitric oxide) bioavailability, which is known to play a crucial role in the development of collateral vessels.

The immunomodulatory effects of unconjugated bilirubin may explain its availability to restrain inflammation. It has also been suggested that serum bilirubin concentration is associated with lower CRP levels via reduction of blood lipid concentration and increased HDL availability and not by direct inhibition of inflammation (38). There is still debate about the effect of hemodialysis on the level of total bilirubin, some studies reporting that after HD the level of total bilirubin (TB) decreases $(38,40-43)$, while others show that it actually remains the same, due to the total bilirubin level (39).

The effects of HD include the removal of circulating antioxidants from the aqueous phase of plasma, leaving proteins vulnerable to oxidation. Although water soluble antioxidants are dialyzed, unconjugated bilirubin, due to its affinity for circulating albumin, is retained in the vascular compartment, therefore being free to react with radicals from the plasma (38). In this context, some studies (38) have suggested that the reduced bilirubin concentration is due to the fact that bilirubin may represent a sacrificial antioxidant.

There are various types of hemodialysis that can impact the final level of bilirubin: intermittent hemodialysis (IHD), continuous venovenous hemofiltration (CVVH), high-volume hemofiltration (HVHF) and plasma exchange (PE) $(40,42)$.

IHD relies on the passive diffusion of the solutes through a semi-permeable membrane, while CVVH is an alternative technique that provides continuous blood purification based on convection driven by a hydrostatic pressure gradient. $\mathrm{HVHF}$ is a form of CVVH that has an ultrafiltration flow rate $>50 \mathrm{~mL} / \mathrm{kg} / \mathrm{h}(40)$.

HVHF followed by IHD appears to have an advantage over IHD alone, evidenced by an earlier decline in the bilirubin level. In the same study (40), total bilirubin, direct and indirect, improved significantly in the HVHF group compared to the IHD group.

Zhang et al. demonstrated that the total bilirubin level decreased at a faster rate in patients treated with CVVH+PE rather than CVVH alone (42).

When comparing the level of TB between people with chronic kidney disease and those on dialysis, the decrease in bilirubin concentration was $65 \%$ lower according to Tbahriti et al. (41) (Table 2).

\section{Alpha-2-macroglobulin and haptoglobin}

Alpha-2-macroglobulin belongs to the group of acute phase proteins and its production is related to inflammation and liver fibrosis. Alpha-2-macroglobulin is also a proteinase inhibitor and its increased synthesis can inhibit the catabolism of matrix proteins and enhance fibrotic processes (44). Haptoglobin decreases when fibrosis increases. This may be a response to the increased hepatocyte growth factor seen in liver damage (45). The positive correlation between fibrosis and $\alpha_{2} \mathrm{M}$ and the negative correlation between fibrosis and haptoglobin could be explained by the different roles of cytokines such as hepatocyte growth factor (HGF) during fibrogenesis. HGF stimulates $\alpha_{2} \mathrm{M}$ synthesis and decreases haptoglobin synthesis (16). Furthermore, in HD patients, the same correlations can be explained 
Table 2. The effect of hemodialysis on the level of bilirubin

\begin{tabular}{lccl}
\hline Authors & Study type & $\begin{array}{c}\text { Number of } \\
\text { patients }\end{array}$ & \multicolumn{1}{c}{ Results } \\
\hline $\begin{array}{l}\text { Boon A C et al., 2014 } \\
(38)\end{array}$ & Review & - & $\begin{array}{l}\text { Bilirubin concentrations are reduced in hemodialysis } \\
\text { patients. }\end{array}$ \\
\hline $\begin{array}{l}\text { Mekki K et al., 2010 } \\
(39)\end{array}$ & Cohort study & 60 & $\begin{array}{l}\text { Bilirubin levels were similar in end-stage liver fail- } \\
\text { ure patients, hemodialysis patients and peritoneal di- } \\
\text { alysis patients. }\end{array}$ \\
\hline Si X et al., 2015 (40) & $\begin{array}{c}\text { Prospective cohort } \\
\text { study }\end{array}$ & 36 & $\begin{array}{l}\text { Total, direct and indirect bilirubin levels were sig- } \\
\text { nificantly lower in patients treated with HVHF than } \\
\text { those treated with IHD alone. }\end{array}$ \\
\hline $\begin{array}{l}\text { Tbahriti HF et al., } \\
\text { 2013 (41) }\end{array}$ & Cohort study & 167 & $\begin{array}{l}\text { Bilirubin levels were diminished (around 65\%) in } \\
\text { patients on hemodialysis compared to chronic kidney } \\
\text { disease patients. }\end{array}$ \\
\hline Zhang L et al. (42) & Retrospective study & 81 & $\begin{array}{l}\text { Serum levels of total bilirubin decreased steadily in } \\
\text { the first 7 days of dialysis. The total bilirubin level } \\
\text { decreased more in the CVVH+ PE than in the CVVH } \\
\text { group. }\end{array}$ \\
\hline Cheng YC et al.(43) & Retrospective study & 327 & $\begin{array}{l}\text { The total bilirubin levels were lower in hemodialysis } \\
\text { patients than in patients with ischemic heart disease } \\
\text { or normal subjects. }\end{array}$ \\
\hline
\end{tabular}

CVVH - continuous venovenous hemofiltration; HVHF - high-volume hemofiltration; IHD - intermittent hemodialysis; PE - plasma exchange

by acute phase reaction induced by the dialysis procedure $(46,47)$. Different variables that formulate the FT scores may be influenced by non-hepatic conditions such as hematoma and immunological factors, which are frequently seen in the hemodialysis population. These conditions may result from high $\alpha_{2} \mathrm{M}$ levels and low haptoglobin levels (49).

Canbakan et al. demonstrated that in HCV hemodialysis patients, the certainty of absence of significant fibrosis (F2-F4) for scores $\leq 0.1$ was only $60 \%$ (19) compared with $100 \%$ in HCV patients with normal renal function (16), and the accuracy of the presence of significant fibrosis for scores $\geq 0.6$ was only $20 \%$ (19) compared with a PPV $\geq 90 \%$ in $\mathrm{HCV}$ patients with normal renal function (16).

A possible reason for the lower diagnostic accuracy may be due to variations in the biochemical components of the FT/AT scores among patients with renal failure. Renal dysfunction may affect results concerning the proteins included in Fibro-
Test. The levels of $\alpha_{2} \mathrm{M}$ may rise in the context of renal insufficiency because of the inflammatory response induced by the dialysis procedure $(46,47)$.

Argiles et al. demonstrated that serum $\alpha_{2} \mathrm{M} \mathrm{lev-}$ els significantly increased from the third hour after initiation of $\mathrm{HD}$, continued to increase for at least $2 \mathrm{~h}$ after the end of dialysis $(\mathrm{P}<0.01)$ and remained elevated at $12 \mathrm{~h}$, independently of the membrane used (AN69 or cuprophane). Since $\alpha_{2} \mathrm{M}$ is related to acute phase reactant proteins, its variations during the dialysis session could represent an inflammatory-like response to the dialysis procedure $(47,48)$.

Decreased serum levels of haptoglobin were observed in the plasma of long-term HD patients. Haptoglobin is a heme-binding glycoprotein that protects the body from hemoglobin-induced oxidative damage, nitric oxide toxicity and pro-inflammatory effects induced by intravascular hemolysis. Haptoglobin also functions as a chaperone that inhibits oxidation-induced 
misfolding of extracellular proteins and thus exerts anti-inflammatory effects. Based on these beliefs, Lin et al. postulated that downregulation of haptoglobin might reflect an exhausted antioxidant reserve in long-term HD patients, while counteracting the persistent deranged redox state and inflammatory stresses (50) (Table 3).

\section{Gamma-glutamyltransferase}

In $\mathrm{CKD}$ on $\mathrm{HD}$, serum GGT levels may be a useful and low-cost marker, similar to aminotransferases, for the diagnosis of chronic $\mathrm{HCV}$ infection (1).

Fabrizi et al. identified an association between serum GGT levels and chronic viral hepatitis $\mathrm{C}$. After analyzing the ROC curve, these authors determined that the best cut-off values to predict positive anti-HCV would be $18 \mathrm{IU} / \mathrm{L}$ (sensitivity $=61 \%$; specificity $=50 \%$ ). These GGT values represent the upper limit of normal (ULN) reductions of $64 \%$ (50 IU/L) for the detection of anti-HCV positive patients (51). Souza et al. also reported higher serum GGT levels in HD patients with $\mathrm{HCV}$ infection than in those negative for anti-HCV $(49.8 \pm 56.6 \mathrm{IU} / \mathrm{L}$ and $94.8 \pm 105 \mathrm{IU} / \mathrm{L}$, respectively) $(\mathrm{p}=0.05)$. Both authors suggested the use of serum GGT levels as an indirect marker to detect liver disease in HD patients, which should be measured monthly for these patients (52).

Liberato et al. evaluated $40 \mathrm{CKD}$ patients on $\mathrm{HD}$ and performed serum GGT dosage immediately prior to and after the dialysis procedure. When divided by the ULN, serum GGT levels were $0.88 \mathrm{IU} / \mathrm{L}$ prior to $\mathrm{HD}$ and $1.14 \mathrm{IU} / \mathrm{L}$ after HD $(p=0.001)$, which is compatible with the increase in serum hematocrit levels, thus characterizing hemoconcentration (hematocrit before $\mathrm{HD}, 36.7 \%$; after HD, 41.3\%, p = 0.001) (53). Therefore, after the dialysis procedure, the mean GGT values were higher than the mean ULN values, suggesting that the serum levels of this enzyme could be reduced in CKD patients prior to the HD session. Ultimately, serum GGT levels in CKD patients on HD are possibly influenced by hemodilution due to the liquid retention of CKD patients (Table 4).

\section{The effect of HD on FibroTest accuracy in predicting the stage of fibrosis}

There are very scarce data regarding the influence of HD on the accuracy of FT in predicting the stage of liver fibrosis.

Although the areas under the ROC curves for the diagnosis of significant fibrosis were similar in the studies of Varaut et al. (0.46) and Canbakan

Table 3. The effect of hemodialysis on the serum levels of a2-macroglobulin and haptoglobin

\begin{tabular}{|c|c|c|c|c|}
\hline Study & Study type & $\begin{array}{c}\text { Influenced } \\
\text { parameter(s) }\end{array}$ & $\begin{array}{l}\text { Number of } \\
\text { patients }\end{array}$ & Results \\
\hline $\begin{array}{l}\text { Argiles et al., } \\
1993(47)\end{array}$ & Prospective & $\alpha_{2} \mathrm{M}$ & 30 & $\begin{array}{c}\text { Serum } \alpha_{2} \mathrm{M} \text { levels significantly increased } \\
\text { from the third hour after initiation of HD, } \\
\text { continued to increase for at least } 2 \mathrm{~h} \text { after } \\
\text { the end of dialysis }(\mathrm{p}<0.01 \text { ) and remained } \\
\text { elevated at } 12 \mathrm{~h} .\end{array}$ \\
\hline $\begin{array}{l}\text { Canbakan et al., } \\
2011(19)\end{array}$ & Prospective & $\begin{array}{l}\text { Fibrosis }\left(\alpha_{2} \mathrm{M},\right. \\
\text { haptoglobin, } \\
\text { TB, GGT, } \\
\text { ApoA1) }\end{array}$ & 33 & $\begin{array}{l}\text { The absence and the presence of significant } \\
\text { fibrosis (F2-F4), determined by FibroTest, } \\
\text { are underestimated in HCV HD patients } \\
\text { compared to HCV patients with normal renal } \\
\text { function. }\end{array}$ \\
\hline $\begin{array}{l}\text { Lin et al., } 2012 \\
(50)\end{array}$ & Prospective & Haptoglobin & 12 & $\begin{array}{l}\text { The protein profile of long-term HD patients } \\
\text { includes decreased serum haptoglobin levels. }\end{array}$ \\
\hline
\end{tabular}


Table 4. The effect of hemodialysis on the serum levels of GGT

\begin{tabular}{|c|c|c|c|}
\hline Study & Study type & $\begin{array}{c}\text { Number of } \\
\text { patients }\end{array}$ & Results \\
\hline $\begin{array}{l}\text { Fabrizi et al., } 2007 \\
(51)\end{array}$ & Retrospective & 333 & $\begin{array}{l}\text { The best cut-off values to predict positive anti-HCV } \\
\text { would be } 18 \mathrm{IU} / \mathrm{L}(\mathrm{Se}=61 \% ; \mathrm{Sp}=50 \%) \text {. These GGT } \\
\text { values represent } \mathrm{ULN} \text { reductions of } 64 \% \text { ( } 50 \mathrm{IU} / \mathrm{L}) \text { for } \\
\text { the detection of anti-HCV positive patients. }\end{array}$ \\
\hline $\begin{array}{l}\text { Souza et al., } 2008 \\
(52)\end{array}$ & Prospective & 87 & $\begin{array}{l}\text { The mean GGT values were higher in patients with } \\
\text { HCV infection than in those without HCV, suggesting } \\
\text { that serum GGT levels could be used as an indirect } \\
\text { marker for detecting liver disease in HD patients. }\end{array}$ \\
\hline $\begin{array}{l}\text { Liberato et al., } 2012 \\
\text { (53) }\end{array}$ & Prospective & 40 & $\begin{array}{l}\text { The levels of serum GGT collected before the dialysis } \\
\text { session were significantly lower than the values ob- } \\
\text { served after dialysis. Also, the hematocrit rates were } \\
\text { significantly lower before dialysis than after the HD } \\
\text { session. }\end{array}$ \\
\hline
\end{tabular}

anti-HCV - anti-hepatitis C virus antibodies; GGT - gamma-glutamyltransferase; HD - hemodialysis; ULN - upper limit of normal

et al. (0.47), the negative predictive value (NPV) of an FT score $<0.2$ and the positive predictive value (PPV) of a score $>0.6$ were significantly different $(15,19)$.

In the first study by Varaut et al., in the analysis of the entire cohort of HD patients, $72 \%$ were correctly classified and the use of FT instead of liver biopsy (LB) meant that $32 \%$ of the LBs could have been avoided. Furthermore, the PPV of a score $>0.6$ was $75 \%$ while the NPV of a score $<0.2$ was $71 \%(15)$.

In contrast, in the study conducted by Canbakan et al., fibrosis was correctly classified in only $33.3 \%$ of all included patients, while LB could have been prevented in $15.15 \%$ of patients with a FT score $<0.2$ and in $3 \%$ of patients with a score $>0.6$. The PPV of a score $>0.6$ was only $20 \%$, while the NPV of a score $<0.2$ was $45.45 \%$ (19).

However, both studies illustrate the idea that the accuracy of FT in HD patients is lower than in the general population and it may reflect the effect of renal disturbances induced by either CKD and/or HD on the biochemical parameters of FT $(15,19)$.

A major strength of the current study is that, to our knowledge, this is the first systematic litera- ture review which evaluates the influence of hemodialysis on FibroTest.

The limitation of this review consists of the relatively small number of studies which reported data regarding the influence of hemodialysis on FibroTest parameters. There are also few papers about FibroTest efficiency in predicting liver fibrosis as compared with other non-invasive methods in hemodialysis patients with hepatitis $\mathrm{C}$ virus infection.

\section{Discussions}

The effect of uremic plasma, and, to a greater extent, of hemodialysis on the level of ApoA1 is to decrease it through increased catabolism and the presence of anti-ApoA1-IgG antibodies. Furthermore, the failure of HD to eliminate the toxins responsible for the inhibition of ApoA1 expression is also responsible for the decreased level of ApoA1.

Although still debatable, most of the studies analyzed in our review suggest that HD tends to decrease the level of TB either by a reduction of the retained TB through the reaction with dialyzed plasma radicals or by the different types of HD utilized: HVHF, IHD and CVVH+PE. 
Serum $\alpha_{2}$-macroglobulin levels may rise in HD patients because of the inflammatory response induced by the dialysis procedure. Increased serum $\alpha_{2} \mathrm{M}$ levels were described from the third hour after initiation of HD until at least 2 hours after the end of dialysis and remained elevated at 12 hours.

Hemolysis and inflammatory status seen in longterm HD patients are the main conditions that lead to decreased levels of haptoglobin in these patients.

In HD patients, serum GGT levels could be influenced by hemodilution due to hypervolemia seen in CKD patients.

\section{Conclusions}

Hemodialysis induces a reduction in ApoA1, haptoglobin and bilirubin levels, but increases GGT and $\alpha_{2}$-macroglobulin levels. These changes could alter the estimation of the fibrosis level indicated by FibroTest in patients undergoing hemodialysis.

\section{Author Contributions}

OHO - Conceptualization, Formal analysis, Investigation, Methodology, Project administration, Resources, Supervision, Validation, Writing - review \& editing.

IB, AMS - Data curation, Formal analysis, Investigation, Resources, Visualization, Writing original draft, Writing - review \& editing AST, SCC, IAM, TA - Formal analysis, Investigation, Resources, Writing - review \& editing AC - Data curation, Formal analysis, Investigation, Resources, Software, Visualization, Writing - original draft, Writing - review \& editing LU, RAO - Conceptualization, Formal analysis, Investigation, Methodology, Project administration, Resources, Supervision, Validation, Visualization, Writing - review \& editing

\section{Conflicts of Interest}

The authors declare that they have no conflicts of interests.

\section{References}

1. Poux JM, Cadranel JF, Fievet P, Dumouchel P, Collot G. Measurement of gamma glutamyl transpeptidase activity: A useful and low-cost tool for the detection of HCV infection in haemodialysed patients. Nephrol Dial Transplant. 1998;13(5):1324. DOI: 10.1093/oxfordjournals.ndt.a027886

2. Pereira BJ, Levery AS. Hepatitis $\mathrm{C}$ virus infection in dialysis and renal transplantation. Kidney Int. 1997;51(4):981-999. DOI: 10.1038/ki.1997.139

3. Weber D, Rutala W, Fried M. Hepatitis C Virus Outbreaks in Hemodialysis Centers: A Continuing Problem. Infection Control \& Hospital Epidemiology. 2016;37(2):140-142. DOI: 10.1017/ice.2015.311

4. Grigorescu M. HCV genotype 1 is almost exclusively present in Romanian patients with chronic hepatitis C. J Gastrointestin Liver Dis. 2009;18(1):45-50.

5. Nițescu M, Vâjâitu C, Săndulescu O, Streinu-Cercel A, Pițigoi D, Preoțescu LL, et al. Non-invasive quantification of liver fibrosis regression following successful treatment of chronic hepatitis $\mathrm{C}$ with direct acting antivirals. Rev Romana Med Lab. 2017;25(4):355-63. DOI: $10.1515 / \mathrm{rrlm}-2017-0030$

6. Chen QW, Cheng CS, Chen H, Ning ZY, Tang SF, Zhang X, et al. Effectiveness and complications of ultrasound guided fine needle aspiration for primary liver cancer in a Chinese population with serum $\alpha$-fetoprotein levels $\leq 200 \mathrm{ng} / \mathrm{ml} \mathrm{-} \mathrm{A} \mathrm{study} \mathrm{based} \mathrm{on} \mathrm{4,312} \mathrm{pa-}$ tients. PLoS One. 2014;9(8) :e101536. DOI: 10.1371/ journal.pone.0101536

7. Dzekova-Vidimliski P, Dzikova S, Selim G, Gelev S, Trajceska L, Pushevski V, Sikole A. Ultrasound predictors of compensated liver cirrhosis in hemodialysis patients with hepatitis C. Saudi J Kidney Dis Transpl. 2013;24(1):30-35. DOI: 10.4103/1319-2442.106235

8. Regev A, Berho M, Jeffers LJ, Milikowski C, Molina EG, Pyrsopoulos NT, et al. Sampling error and intraobserver variation in liver biopsy in patients with chronic HCV infection. Am J Gastroenterol. 2002;97(10):26142618. DOI: 10.1111/j.1572-0241.2002.06038.x

9. Orasan OH, Orasan RA, Patiu IM, Dumitrascu DL. Hyaluronic acid in end-stage renal disease treated by hemodialysis. Ren Fail. 2015;37(9):1531-1532. DOI: 10.3109/0886022X.2015.1077312

10. Orasan $\mathrm{OH}$, Urian L, Ciulei G, et al. Thrombocytopenia in end-stage renal disease and chronic viral hepatitis B or C. J Mind Med Sci. 2018;5(2):236-243. DOI: 10.22543/7674.52.P236243 
11. Jiang Y, Huang E, Mehrnia A, Kamgar M, Pham PT, Ogunorunyinka $\mathrm{O}$, et al. Can aminotransferase-to-platelet ratio index and other non-invasive markers effectively reduce liver biopsies for renal transplant evaluation of hepatitis $C$ virus-positive patients? Nephrol Dial Transplant. 2014;29(6):1247-1252. DOI: 10.1093/ndt/ gft485

12. Parkes J, Guha IN, Roderick P, Rosenberg W. Performance of serum marker panels for liver fibrosis in chronic hepatitis C. J Hepatol. 2006;44(3):462-474. DOI: $10.1016 /$ j.jhep.2005.10.019

13. Castera L, Forns X, Alberti A. Non-invasive evaluation of liver fibrosis using transient elastography. J Hepatol. 2008;48(5):835-847. DOI: 10.1016/j.jhep.2008.02.008

14. Liu CH, Liang CC, Huang KW, Liu CJ, Chen SI, Lin JW, et al. Transient Elastography to Assess Hepatic Fibrosis in Hemodialysis Chronic Hepatitis C Patients. Clin J Am Soc Nephrol. 2011;6(5):1057-1065. DOI: 10.2215/CJN.04320510

15. Varaut A, Fontaine H, Serpaggi J, Verkarre V, Vallet-Pichard A, Nalpas B, et al. Diagnostic accuracy of the fibrotest in hemodialysis and renal transplant patients with chronic hepatitis C virus. Transplantation. 2005;80(11):1550-1555. DOI: $10.1097 / 01$. tp.0000183399.85804.02

16. Imbert-Bismut F, Ratziu V, Pieroni L, Charlotte F, Benhamou Y, Poynard T. Biochemical markers of liver fibrosis in patients with hepatitis $\mathrm{C}$ virus infection: a prospective study. Lancet. 2011;357(9262):1069-1075. DOI: 10.1016/S0140-6736(00)04258-6

17. Castéra L, Vergniol J, Foucher J, Le Bail B, Chanteloup E, Haaser M, et al. Prospective comparison of transient elastography, Fibrotest, APRI, and liver biopsy for the assessment of fibrosis in chronic hepatitis C. Gastroenterology. 2005;128(2):343-350. DOI: 10.1053/j.gastro.2004.11.018

18. Mikolasevic I, Orlic L, Zaputovic L, Racki S, Cubranic $\mathrm{Z}$, Anic K, et al. Usefulness of liver test and controlled attenuation parameter in detection of nonalcoholic fatty liver disease in patients with chronic renal failure and coronary heart disease. Wien Klin Wochenschr. 2015;127(11-12):451-458. DOI: 10.1007/s00508-015$0757-z$

19. Canbakan M, Senturk H, Canbakan B, et al. Validation of biochemical markers for the prediction of liver fibrosis and necroinflammatory activity in hemodialysis patients with chronic hepatitis C. Nephron Clin Pract. 2011;117(3):289-296. DOI: 10.1159/000320751

20. Moher D, Liberati A, Tetzlaff J, Altman DG, Group P. Preferred reporting items for systematic reviews and meta-analyses: the PRISMA statement. PLoSmedicine. 2009;6(7):e1000097. DOI: 10.1371/journal. pmed.1000097

21. Moradi H, Said HM, Vaziri ND. Post-transcriptional nature of uremia-induced downregulation of he- patic apolipoprotein A-I production. Transl Res. 2013;161(6):477-485. DOI: 10.1016/j.trsl.2012.11.001

22. Pruijm M, Schmidtko J, Aho A, Pagano S, Roux-Lombard P, Teta D, et al. High Prevalence of Anti-Apolipoprotein/A-1 Autoantibodies in Maintenance Hemodialysis and Association With Dialysis Vintage. Ther Apher Dial. 2012;16(6):588-594. DOI: 10.1111/j.17449987.2012.01102.x

23. Rolla R, De Mauri A, Valsesia A, Vidali M, Chiarinotti D, Bellomo G. Lipoprotein profile, lipoprotein-associated phospholipase A2 and cardiovascular risk in hemodialysis patients. J Nephrol. 2015;28(6):749-755. DOI: $10.1007 / \mathrm{s} 40620-015-0194-0$

24. Calabresi L, Simonelli S, Conca P, et al. Acquired lecithin: Cholesterol acyltransferase deficiency as a major factor in lowering plasma HDL levels in chronic kidney disease. J Intern Med. 2015;277(5):552-561. DOI: 10.1111/joim. 12290

25. Moradi H, Pahl MV, Elahimehr R, Vaziri ND. Impaired antioxidant activity of high-density lipoprotein in chronic kidney disease. Transl Res. 2009;153(2):77-85. DOI: $10.1016 / \mathrm{j} . \operatorname{trs} 1.2008 .11 .007$

26. Pahl MV, Ni Z, Sepassi L, Moradi H, Vaziri ND. Plasma phospholipid transfer protein, cholesteryl ester transfer protein and lecithin:cholesterol acyltransferase in endstage renal disease (ESRD). Nephrol Dial Transplant. 2009;24(8):2541-2546. DOI: 10.1093/ndt/gfp120

27. Kaysen GA, Dalrymple LS, Grimes B, Chertow GM, Kornak J, Johansen KL. Changes in serum inflammatory markers are associated with changes in apolipoprotein A1 but not B after the initiation of dialysis. Nephrol Dial Transplant. 2014;29(2):430-437. DOI: 10.1093/ ndt/gft 370

28. Honda H, Hirano T, Ueda M, Kojima S, Mashiba S, Hayase Y, et al. High-Density Lipoprotein Subfractions and Their Oxidized Subfraction Particles in Patients with Chronic Kidney Disease. J Atheroscler Thromb. 2016;23(1):81-94. DOI: 10.5551/jat.30015

29. Ribeiro S, do Sameiro Faria M, Mascarenhas-Melo F, Freitas I, Mendonça MI, Nascimento H, et al. Main determinants of PON1 activity in hemodialysis patients. Am J Nephrol. 2012;36(4):317-323. DOI: $10.1159 / 000342235$

30. Kimak E, Hałabiś M, Baranowicz-Gąszczyk I, Solski J, Książek A. Association between moderately oxidized low-density lipoprotein and high-density lipoprotein particle subclass distribution in hemodialyzed and post-renal transplant patients. J Zhejiang Univ Sci B.2011;12(5):365-371. DOI: 10.1631/jzus.B1000348

31. Lokesh S, Kadavanu TM,Green SR, et al. A Comparative Study of Lipid Profile and Cardiovascular Risk Biomarkers Among Chronic Haemodialysis Patients and Healthy Individuals. J Clin Diagnostic Res. 2016;10(9):36-40. DOI: 10.7860/ JCDR/2016/21897.8523 
32. Ikewaki K. In vivo kinetic studies to further understand pathogenesis of abnormal lipoprotein metabolism in chronic kidney disease. Clin Exp Nephrol. 2014;18(2):261-264. DOI: 10.1007/s10157-0130881-x

33. Yeo Y, Byun SW, Lee JY, Min WK, Park JS, Kim SB. Lack of association between small dense low-density lipoprotein levels and coronary artery disease in chronic hemodialysis patients. Am J Nephrol. 2009;30(3):310314. DOI: $10.1159 / 000225939$

34. Samouilidou EC, Grapsa E. Relationship of serum cystatin $\mathrm{C}$ with $\mathrm{C}$-reactive protein and apolipoprotein $\mathrm{A} 1$ in patients on hemodialysis. Ren Fail. 2008;30(7):711715. DOI: 10.1080/08860220802212973

35. Wu S, Chen X, Yuan S, Peng D, Zhou A, Li J. Impaired cholesterol efflux capacity is related to increased carotid intima media thickness in patients with end-stage renal disease. Int J Cardiol. 2015;187(1):456-458. DOI: 10.1016/j.ijcard.2015.03.362

36. Moradi H, Said HM, Vaziri ND. Post-transcriptional nature of uremia-induced downregulation of hepatic apolipoprotein A-I production. Transl Res. 2013;161(6):477-485. DOI: 10.1016/j.trsl.2012.11.001

37. Holzer M, Birner-Gruenberger R, Stojakovic T, et al. Uremia Alters HDL Composition and Function. J Am Soc Nephrol. 2011;22(9):1631-1641. DOI: 10.1681/ ASN.2010111144

38. Boon AC, Bulmer AC, Coombes JS, Fassett RG. Circulating bilirubin and defense against kidney disease and cardiovascular mortality: mechanisms contributing to protection in clinical investigations. AJP Ren Physiol. 2014;307(2):F123-136. DOI: 10.1152/ajprenal.00039.2014

39. Mekki K, Taleb W, Bouzidi N, Kaddous A, Bouchenak M. Effect of hemodialysis and peritoneal dialysis on redox status in chronic renal failure patients: a comparative study. Lipids Health Dis. 2010;9:93. DOI: 10.1186/1476-511X-9-93

40. Si X, Li J, Bi X, Wu L, Wu X. Clinical evaluation of high-volume hemofiltration with hemoperfusion followed by intermittent hemodialysis in the treatment of acute wasp stings complicated by multiple organ dysfunction syndrome. PLoS One. 2015;10(7):1-11. DOI: 10.1371/journal.pone. 0132708

41. Tbahriti HF, Kaddous A, Bouchenak M, Mekki K. Effect of Different Stages of Chronic Kidney Disease and Renal Replacement Therapies on Oxidant-Antioxidant Balance in Uremic Patients. Biochem Res Int. 2013;2013:1-6. DOI: 10.1155/2013/358985

42. Zhang L, Yang Y, Tang Y, Zhao Y, Cao Y, Su B, et al. Recovery from AKI following multiple wasp stings: A case series. Clin J Am Soc Nephrol. 2013;8(11):18501856. DOI: $10.2215 / \mathrm{CJN} .12081112$

43. Cheng YC, Kuo WW, Wu CH, Shu WT, Kuo CH,
Hwang JM, et al. Iron status and cardiovascular risk factors in patients with haemodialysis versus patients with ischaemic heart disease. Nephrol. 2009;14(1):6569. DOI: 10.1111/j.1440-1797.2008.01004.x

44. Poynard T, Imbert-Bismut F, Ratziu V, Chevret S, Jardel C, Moussalli J, et al. Biochemical markers of liver fibrosis in patients infected by hepatitis $\mathrm{C}$ virus: longitudinal validation in a randomized trial. $\mathrm{J}$ Viral Hepat. 2002;9(2):128-133. DOI: 10.1046/j.13652893.2002.00341.x

45. Bacq Y, Schillio Y, Brechot JF, De Muret A, Dubois F, Metman EH. Decrease of haptoglobin serum level in patients with chronic viral hepatitis C. Gastroenterol Clin Biol. 1993;17(5):364-369.

46. Trznadel K, Luciak M, Paradowski M, Kubasiewicz-Ujma B. Hemodialysis and the acute-phase response in chronic uremic patients. Int J Artif Organs. 1989;12(12):762-765. DOI: 10.1177/039139888901201205

47. Argilés A, Kerr PG, Mourad G, Mion CM, Atkins RC. Serum alpha 2-macroglobulin in haemodialysis patients: baseline and kinetic studies. Nephrol Dial Transpl. 1993;8(10):1118-1123.

48. Petrauskiene V, Vaiciuniene R, Kuzminskis V, Ziginskiene E, Grazulis S, Jonaitiene E, et al. Associations of vascular calcification, calcium phosphate disturbances, FGF 23 and Matrix Gla protein with mortality of hemodialysis patients: one center cohort study. Rev Romana Med Lab. 2018;26(4):451-60. DOI:10.2478/ rrlm-2018-0034. DOI: 10.2478/rrlm-2018-0034

49. Maor $Y$, Calès $P$, Bashari $D$, et al. Improving estimation of liver fibrosis using combination and newer noninvasive biomarker scoring systems in hepatitis C-infected haemophilia patients. Haemophilia. 2007;13(6):722729. DOI: $10.1111 / j .1365-2516.2007 .01548 . x$

50. Lin YP, Yang CY, Liao CC, Yu WC, Chi CW, Lin CH. Plasma protein characteristics of long-term hemodialysis survivors. PLoS One. 2012;7(7):e40232. DOI: 10.1371/journal.pone.0040232

51. Fabrizi F, de Vecchi AF, Qureshi AR, et al. Gamma glutamyltranspeptidase activity and viral hepatitis in dialysis population. Int J Artif Organs. 2007;30(1):6-15. DOI: $10.1177 / 039139880703000103$

52. Souza JF, Longui CA, Miorin LA, Sens YA. Gamma-Glutamyltransferase Activity in Chronic Dialysis Patients and Renal Transplant Recipients With Hepatitis C Virus Infection. Transplant Proc. 2008;40(5):13191323. DOI: 10.1016/j.transproceed.2008.03.157

53. Liberato I, Lopes E, Cavalcante M, Pinto T, Moura I, Loureiro-Jr L. Liver enzymes in patients with chronic kidney disease undergoing peritoneal dialysis and hemodialysis. Clinics. 2012;67(2):131-134. DOI: 10.6061/clinics/2012(02)07 